\title{
Study of Literature Transformation in Bedhaya Hagoromo Dance
}

\author{
Denny Eko Wibowo \\ Universal University Batam \\ e-mail: denny.wibowo84@gmail.com \\ Muhammad Fazli Taib Saearani \\ Sultan Idris Education University \\ e-mail: fazli@fmsp.upsi.edu.my
}

Published online: 29 June 2020

Cite this article (APA): Wibowo, D. E. \& Saearani, M. F. T. (2020). Study of literature transformation in Bedhaya Hagoromo dance. Jurai Sembah, 1(1), 25-34. https://doi.org/10.37134/juraisembah.vol1.1.3.2020

\begin{abstract}
Bedhaya Hagoromo dance was arranged by Didik Nini Thowok in 2001, and last performed in 2014. The dance was adapted from Jaka Tarub Nawang Wulan folklore and Hagoromo stage play which was manifested into its dancing composition. This literature transformation contained the plot adapted from folklore literature into the bedhaya dance literature, creating a unique assemblage. The purpose of this study is to identify the form of literature transformation and to study the elements performed in the dance. The qualitative research method in this study is literature transformation approach, namely by observing the parts of this dance that are in accordance with the default framework of bedhaya dance. From the observation, the literature transformation has shown a collaboration of Javanese and Japanese folklores through the language that can be understood well by Javanese. Therefore, this indirectly helps in reviving the bedhaya kakung dance to this day.
\end{abstract}

Keywords: Bedhaya Hagoromo, choreography, literature transformation

\section{Introduction}

Various traditions are inherited by one generation to the next in numerous forms. One of these are traditional stories, that are still developed and well-maintained by certain societies. The traditional stories which include legends, myths, chronicles, and epos may encounter challenges in preserving their existence. Overcoming of the challenges will depend on the efforts of transmitting these stories from one generation to the other, which is still done by noble people. The emergence of various innovations and knowledge development through the role of information technology is considered as a good platform for alternatives in the efforts of preserving the traditional art form, even though traditional art is still considered more cultured in its distinctive inheritance patterns. Folklores, which are originally passed down orally from generation to generation, can now be performed as soap operas with help of cinematography and technology, which are watched and easier understood by most people. For example, Lenong Legenda that premiered on 23 June 2018 by MNCTV channel displayed a lot of literature transformation's patterns which were adapted from folk stories in Indonesia. Lenong Legenda had also made use of cinematography in the media, within the framework of the traditional drama Lenong, although in the manifestation, reduction of folklore was involved. However, the folklore reduction was still conserved in the society until now. Unlike Lenong Legenda, Riri Cerita Anak Interaktif had been striving since 2013, to present Indonesian folklores in the form of animation show. This is related to the purpose of Riri as an entertainment media as well as interesting education for kids (http://www.riri.id/about-us). Another form of literature transformation is the literary works, such as novel or poem which have been adapted into movies. For examples, Indonesian movies such as Hujan Bulan Juni which aired on 2 November 2017 was adapted from a poem written by Sapardi Djoko Damono in 1991, whereas the movie entitled Bumi Manusia which premiered on 15 August 
2019, was adapted from Pramoedya Ananta Toer's published novel in 1980. Both were presented in the movies with the same titles as the literary work.

The transformation activity mentioned above, gives the insight that the change from a single art entity (a medium) to other art entities (several mediums) portrays good processes of adaptation by reducing or adding the factors or elements that are sometimes needed in order to meet the new criteria. As Damono (2018) asserts, "this may be referred as literature transformation, which means the conversion from one type of literary artwork to another that includes translation, editing, and transmission activities" (p. 9). This literature transformation often happens to traditional stories or literary works in the form of revised play, either traditionally performed on stage, television or silver screen, which engages the role of digital technology. Such conditions, not limiting to the study of literature transformation in those forms, are rather unique when it can be diverted into another art media, such as dance.

Stage performances that convey the form of certain literature transformation, is directly dealing with the audience at the same place and time. As with the stage play performance, dance performances should at least be able to convey the purpose and message of the literature through a particular language. This factor too, relates to the ability of the audience in understanding the language that they have already known (Damono, 2018). Therefore, the importance of understanding dance as a new medium that emerges from the previous literary medium cannot be done only by observing the textual aspect, but also the contextual meaning which mainly occurs in traditional dance performances.

The object in this study is Bedhaya Hagoromo dance which was last performed by Didik Nini Thowok during his $60^{\text {th }}$ anniversary celebration in 2014. Bedhaya Hagoromo is a masterpiece that has an interesting background of creation. This is due to the form of its presentation, that has become very distinctive as a mixture of two traditional art entities. Its existence is regarded as a way of contribution from Didik Nini Thowok as a cross-gender artist to Sri Sultan Hamengku Buwono X and all citizens of Yogyakarta (Wibowo, 2018).

The study of literature transformation from folklore to the dance has become a complex subject when it is examined in the process of merging two different traditions from two distinct cultural background, into one genre of bedhaya dance, typical of Javanese. Bedhaya Hagoromo was created by Didik Nini Thowok in 2001, and has been performed three times using the form of appearance that is in accordance with each event. Wibowo (2015) added that "nevertheless, the story adapted from the dance of Bedhaya Hagoromo remains the same as the story of Jaka Tarub Nawang Wulan which has collaborated with the story of Hagoromo from one of the Noh plays in Japan" (pp. 1-2).

This study has restricted the discussion of the patterns and processes of the literature transformation, into the scope of its occurrence from the folklore to a type of bedhaya dance (a dance which is performed by 9 females). Therefore, this study has observed and analyzed the patterns and processes of the literature transformation from the folklore into the arrangement of choreography. The purpose is to observe the adaptations that have occurred in the Bedhaya Hagoromo dance, either conceptually or contextually.

\section{Research Methods}

This research has been conducted using qualitative methods by data collection and literature review. Data collection was obtained through observation of the participants', specifically during the last stage performance of Bedhaya Hagoromo dance in Yogyakarta. The author also performed as the dancer in the last stage of the performance and had also been involved in assisting the composition process of the dance.

The literature review was done in order to obtain data and information from local experts among Javanese citizens in Yogyakarta, relating to the dance genre of bedhaya with all its distinctive performance features. This research utilizes ethnochoreology approach where it relates directly to the life of its proprietor. The bedhaya dance genre is one of the exclusive dances in Javanese court performing arts because this dance has many symbolizations and rules that are linked with Javanese perspective and philosopy in their lives. The study incorporates the theory of literature transformation by Sapardi Djoko Damono where its analysis process involves an approach of choreography analysis too. The transformation from one entity to another (from folklore to dance composition) in a creative work of performing arts, was done in intertextual condition. 


\section{Literature Review}

Mainly, the study of literature transformation refers to the medium transformation from folklore or literary works into movies (cinematography) and/or stage play performances. This kind of study is rarely done in dance performances which are also originated from folklore or literary works in the form of sêrat (Javanese manuscript). If there are any research and studies on that matter, it is more geared to the form of literature transformation which has materialized in accordance with the flexibility of the creator of the dance work. Some of the dance works in Javanese palaces have mostly adapted their traits from the story or characterization of legends, like Mahabarata, Anglingdarma, Panji, even sêrat or manuscripts written by kings or royal families at that time. Srimpi Nadheg Putri is "one of the examples of dance works compiled based on the embodiment of wedana renggan (pictures) on the text of Langen Wibawa during the reign of Sri Paku Alam IV (1864-1878) and Sri Paku Alam V (1878-1900) by AM. Hermien Kusmayati in 2012" (Kusmayati, 2015, pp. 157 \& 165).

The lack of studies on the literature transformation of dance works is due to the fact that in terms of dance and dance theme mediums, they are relatively normal. Therefore, the study is often limited to the scope of choreography analysis. On the other hand, literature transformation relates to the ability to derive and present the analysis of previous forms of mediums, adjusted to become new mediums, conceptually and technically.

The theory of literature transformation will also relate to the concept of intertextuality, which is the text realized as a result of this transformation being the set of pre-existing texts. There is a connection between the compilation of texts and the meaning interpreted by the recipient, in this case the reader or viewer. The process of medium transformation, according to Damono, is essentially "not the transformation itself, but what is contained in it" (2018, p. 13). Discussion of literature transformation on the dance medium will include the analysis of the choreography covering aspects of form and technique (Hadi, 2011).

\section{Discussion}

\section{The Collaboration between the folklores, Jaka Tarub Nawang Wulan and Hagoromo in the Bedhaya Hagoromo dance.}

Didik Nini Thowok arranged the dance of Bedhaya Hagoromo based on his experience as an artist in learning Javanese dance, and Hagoromo plays from Noh, the traditional Japanese drama. It is described by Didik Nini Thowok that the background of this dance creation was also morally supported by the late B.R.Ay. Yudanegara (Wibowo, 2018). Great support and motivation were also developed when this dance, Bedhaya Hagoromo, was performed again as the third time which was deliberately presented to Sri Sultan Hamengku Buwono $\mathrm{X}$ and the citizens of Yogyakarta, as an expression of gratitude for the opportunity to be an artist, which Didik Nini Thowok has acquired for 40 years since living in Yogyakarta. This gratitude is written in the poetry kandha (a poem that is sung by the pemaoskandha or the dance narrator in the opening of the court dance) and sindhenan (a poem that is sung by the sindhen or waranggana, referring to the singer in the karawitan music group) of his dance harmony.

Sebetbyar wauta, hanenggih hingkang kapitontonaken punika, lelangen bedaya Hagoromo, yasanipun sanggar tari Natyalakshita, pinangka pisungsun katur, Ngarsa Dalem Hingkang Sinuwun, Kanjeng Sultan Hamengku Buwana, Hingkang Jumeneng kaping Sedasa, hing nagari Ngayogyakarta Hadiningrat.

Wauta, sareng sampun sami munggweng saana taya, dasar sami endahing kang warna, karengga hing busana habra, yen sinawang saking mandrawa, lir mulat bebondhetan sampurarira.

Translation:

Sabetbyar wauta, which means performed now, is the Bedhaya Hagoromo dance, the work creation of Natya Lakshita dance studio, presented to Sri Sultan Hamengku Buwono X in Yogyakarta. Wauta means already standing in the stage of dance, getting dressed up beautifully that when it is viewed from a distance, the shawl appears to be embedded (in a harmony of bondhet) (Wibowo, 2018). 


\author{
"Lir bondhet swaranya \\ cihnaning raos manembah sampun kawan ndasa warsa Babo” (Wibowo, 2015, pp. 124-125).
}

Free translation:

In the harmony of bondhet, right in the sense of the forty years of worship, Babo.

In addition, to convey the intent and purpose of Bedhaya Hagoromo dance performances in 2014 would involve the use of the dance's storyline, referring to the legend of Jaka Tarub Nawang which is also portrayed clearly through the lines of Sindhenan poetry in the Gendhing Bondhet, Ladrang Prabu Dewa, and Ketawang Langen Gita (Wibowo, 2015). Referring to the kandha and sindhenan poems, the purpose of last stage performance was portrayed, and composition of the Bedhaya Hagoromo dance was done by Didik Nini Thowok.

The imagination of Didik Nini Thowok in crafting this creative dance choreography is backed by an unassuming collaborative pattern. It relates to two folklores which are combined into a bedhaya genre dance. Nevertheless, Didik Nini Thowok does not see any difference as an obstacle, but closely monitors the similarities between the two, and taking it as a challenge to make a dance collaboration. The collaboration of two stories in Bedhaya Hagoromo dance is one of the creative actions of Didik Nini Thowok which not only relates to his individual aspects as a cross-gender artist, but also the cultural aspect (the domain) and the social space (the field) that provide the opportunity to apply the tradition of bedhaya kakung (the type of bedhaya dance which is performed by 9 males)in the present day (Wibowo, 2018).

According to Didik Nini Thowok, the story of Jaka Tarub Nawang Wulan in Central Java's folklore is originated from Babad Pajang and relates to the existence of Nyai Lara Kidul (Didik Nini Thowok, personal communication, August 1, 2018). This information is emphasized by the explanation of Bidadari Nawang Wulan who turned into Nyai Lara Kidul as a Path of Kanjeng Ratu Kidul and her figure is also regarded as the ancestor of the emperors (Surjodiningrat, 1971). In fact, similarities of the nymph figures portrayed in the two folklores become the important basis that strengthens how Didik Nini Thowok involves the characters in his work. The angel figure of Nawang Wulan is similar to the angel figure that exists in Hagoromo play from Japan. Didik Nini Thowok is experienced to see the probability of this chance through Hagoromo play that he learned while studying the drama of Noh in Japan (Didik Nini Thowok, personal communication, September 8, 2014).

Hagoromo it self is a traditional Japanese story which is embodied in Hagoromo'splay for Noh drama. Hagoromo was interpreted as an angel's 'flying robe' found by Hakuryō, and the angel performed the sky dance (surugamai) requested by Hakuryō when the angel asked for her robe back (Bowers, 1984). Although these two stories show the same emphasis, the original story had a different ending. The story of Jaka Tarub Nawang Wulan ended with a marriage, while the play of Hagoromo ended with the angel (Bidadari) leaving back to the sky after dancing in front of Hakuryō.

The collaborative work of these two stories imply that the combination has equal proportions, either from the composition terms and/or the elements involved. Some patterns of the collaborative work will even be more impressive, for example the mutual domination of other entities. This might happen because not all elements of another collaborative work can be included in the combined spaces or interculturally. The collaboration does not determine which part is 'mastered,' but rather, how the parts are balanced with each other to form a good combination. It also happens in the Bedhaya Hagoromo dance by Didik Nini Thowok.

The collaboration between the stories of Jaka Tarub Nawang Wulan from Java and Hagoromo from Japan fills up the composition of bedhaya dance. The end of the story of Jaka Tarub Nawang Wulan could be merged into the story of Hagoromo, therefore not necessary to indicate which part of the story is presented. This collaborative work, apart from the similarities found by Didik Nini Thowok in the existing character, also portrays the presentation of bedhaya and the meditative Noh where the differences are featured. Although the melody of the Japanese musical instrument is not aligned with the 'tone' of gamelan, it could be mixed well without distracting the gamelan musical traits during the performance. To emphasize, the collaborative Bedhaya Hagoromo dance does not mean the proportions between the Javanese cultural entities and the Japanese cultures conveyed through the story of Jaka Tarub Nawang Wulan-Hagoromo as well as the Javanese dance (a variety of Putri's dance for Bedhaya) and movements of Noh are equally divided. Both are of the same quality, but the way of filling the parts of the dance are adjusted, in which the 
frame of bedhaya dance becomes the foothold of creation in the collaboration, so that the movements of Hagoromo and Noh could be included in the Bedhaya dance

The balance in the collaboration is not the same as predicted before. However, satisfaction could be achieved from the contribution, interaction, and quality of the results where some of the actors will play the 'active' role, while the others play the 'passive' role. Switching between roles and flexibility of movements help to reach the balance and equality at the next stage (Dea, 2005).

Cultures that have preceded Javanese customs and traditions may have played a significant role in shaping the Javanese culture we know of today. The epic of Ramayana and Mahabarata are presented in the form of Carangan stories; for example, Bedhaya Sinom told a story about Menak Cina who was involved in a war between Dewi Kuroisyin and Dewi Widaningrum; Wayang Golek Menak featured Chinese characters, or Srimpi Muncar took a story of the conflict between Dewi Kelaswara and Dewi Adaninggar who fought over Jayengrana. The openness to many cultures signifies the acceptance of the human rights and equality derived from other cultures, where clashes of values do not occur. The value of Javanese culture such as 'nrima' or 'pasrah' (surrender) is the intermediary between two different cultural values in order not to clash with each other (Dea, 2005). Moreover, the Japanese cultural value of Hagoromo and Noh play are now included in the dance of Bedhaya Hagoromo. In fact, collaborative work was portrayed by Didik Nini Thowok in the case of the choreographer's name. Due to the dance being a masterpiece by Didik Nini Thowok, that also shows tribute or homage to Sri Sultan Hamengku Buwono X, the collaboration processes involve other artistes, for example in dance music by Sunardi who arranged the Javanese instrumental music featuring Richard Emmert for the Noh music aspect.

\section{Identification of Novelty in The Process of Literature Transformation from The Story of Jaka Tarub Nawang Wulan and Hagoromo in Bedhaya Hagoromo Dance}

The collaboration between Jaka Tarub Nawang Wulan and Hagoromo plays have also helped to engage the socio-cultural aspect of Javanese and Japanese people which exist in Bedhaya dance and Noh drama. The name of Bedhaya Hagoromo uses the term 'bedhaya' as the main unit of dance patterns that meets the classical dance rules of the Javanese palace. The name of Hagoromois chosen because its play is set up in the concept of dance, although in kandha and pasindhenan poems, details of the Jaka Tarub Nawang Wulan story are featured more. This shows the acceptance of other cultural values to be merged into the Javanese culture (Javanese art dance) created by Didik Nini Thowok in terms of the tolerance of 'tepa salira' and 'narima' (accepting whatever happens).

Suharti (2015) wrote that "the meaning of bedhaya comprises of three points, which are denotative, connotative, and royal life meanings in the Kasultanan Ngayogyakarta Hadiningrat Palace" (p. 98). The context of Bedhaya in the Bedhaya Hagoromo dance refers to its denotative meaning as a pattern of palace dance and is still interpreted as an elite artwork from Yogyakarta Sultanate Palace for the people in Yogyakarta and surrounding areas.

The identification of transformation mediums of Jaka Tarub Nawang Wulan story and HagoromoNoh movement aims to observe the changes and adjustments that occur by looking at the dance structure of Bedhaya Hagoromo.

Bedhaya Hagoromo is divided into three main parts, namely the beginning, middle, and the where each part is linked to one another through the floor or raft, 'rakit' pattern. Raft, 'rakit' is a floor pattern of bedhay a formed by nine dancers who follow certain guidelines while also showing explanation of the parts and dance structures. The raft, 'rakit' used in Bedhaya Hagoromo refers to the standard rakit bedhaya, such as lajur, ajeng-ajengan, iring-iringan, mlebet-medhal lajur, tiga-tiga, and gelar. Generally, a bedhaya traditional dance presents several dance stories using the title of rakit, as well as the dance of Bedhaya Hagoromo.

The literature transformation of Jaka Tarub Nawang Wulan story and Hagoromo (Noh drama) was created by Didik Nini Thowok in several parts. The result was not only manifested in the arrangement of choreography, but also in the form of make-up and costume styling which became the whole part of stage presentation. Almost all dancers wear the same make-up and costume, except the roles of batak and endhel dancers, where they are given special accessories to show the characterization of Jaka Tarub Nawang Wulan or goddesses as shown in the Table 1 and Figure 1 and 2 below. 
Table 1: Identification of literature transformation in the story of Jaka Tarub Nawang Wulan with Hagoromo play.

\begin{tabular}{|c|c|c|c|}
\hline \multirow{2}{*}{$\begin{array}{c}\text { Part of } \\
\text { dance }\end{array}$} & \multirow{2}{*}{$\begin{array}{c}\text { The sequence of } \\
\text { Bedhaya } \\
\text { Hagoromo } \\
\text { perfomance }\end{array}$} & \multicolumn{2}{|c|}{ Form of Literature transformation } \\
\hline & & $\begin{array}{l}\text { Adapted from Jaka Tarub and } \\
\text { Nawang Wulan folklore }\end{array}$ & $\begin{array}{l}\text { Adapted from Hagoromo plays } \\
\text { (Japanese folklore) }\end{array}$ \\
\hline \multirow[t]{2}{*}{$\begin{array}{l}\text { Beginning } \\
\text { (maju } \\
\text { beksan) }\end{array}$} & & & $\begin{array}{l}\text { Akira Matsui play a role like waki } \\
\text { in Noh drama performance, but in } \\
\text { this dance, he lead the group of } \\
\text { bedhaya dancer going to the stage } \\
\text { with Kapang-kapang maju. }\end{array}$ \\
\hline & & & $\begin{array}{l}\text { Sung of kandha with Noh drama } \\
\text { accentuate poem or song }\end{array}$ \\
\hline \multirow[t]{3}{*}{$\begin{array}{l}\text { Main } \\
\text { (beksan) }\end{array}$} & \multirow{3}{*}{$\begin{array}{l}\text { Rakit lajur }- \\
\text { rakit medhali } \\
\text { lajur - rakit } \\
\text { melebet lajur - } \\
\text { rakit tiga-tiga - } \\
\text { rakit jejer (in one } \\
\text { line to put on the } \\
\text { mask) - rakit } \\
\text { tiga-tiga - rakit } \\
\text { gelar - rakit } \\
\text { tiga-tiga }\end{array}$} & $\begin{array}{l}\text { Sung pasindhenan poem in } \\
\text { Gendhing Bondhet, ladrang } \\
\text { Prabu Dewa, and ketawang } \\
\text { Langen Gita }\end{array}$ & $\begin{array}{l}\text { Rakit jejer (in one line to put the } \\
\text { mask) to feature the part of } K o \text { - } \\
\text { omote mask wearing }\end{array}$ \\
\hline & & $\begin{array}{l}\text { Combination dance motion } \\
\text { between ngenceng encot with } \\
\text { Noh motion use a fan }\end{array}$ & $\begin{array}{l}\text { Motion of shikake, hiraki, and } \\
\text { kamae that combine with } \\
\text { ngenceng encot motion (Javanese } \\
\text { dance) }\end{array}$ \\
\hline & & $\begin{array}{l}\text { In Rakit Gelar presenting the } \\
\text { story of Jaka Tarub Nawang } \\
\text { Wulan (beginning from the } \\
\text { nymphs down to earth until they } \\
\text { are goung back to heaven) }\end{array}$ & $\begin{array}{l}\text { In Rakit Gelar also presenting } \\
\text { dance motion of Hagoromo plays } \\
\text { after presenting story of Jaka } \\
\text { Tarub Nawang Wulan. There are } \\
\text { playing collaboration music } \\
\text { instrument between gamelan and } \\
\text { Noh music instrument }\end{array}$ \\
\hline $\begin{array}{l}\text { Ending } \\
\text { (mundur } \\
\text { beksan) }\end{array}$ & \begin{tabular}{lr}
\multicolumn{2}{l}{ Kapang-kapang } \\
mundur & (in \\
specific floor \\
design, not in \\
rakit & lajur/ \\
bedhaya & floor \\
design) & \\
\end{tabular} & $\begin{array}{l}\text { The changing of floor design in } \\
\text { "V" shape accompanied } \\
\text { Monggang music. This part is a } \\
\text { symbolic homage to Sri Sultan } \\
\text { Hamengku Buwono X by Didik } \\
\text { NiniThowok. }\end{array}$ & \\
\hline
\end{tabular}

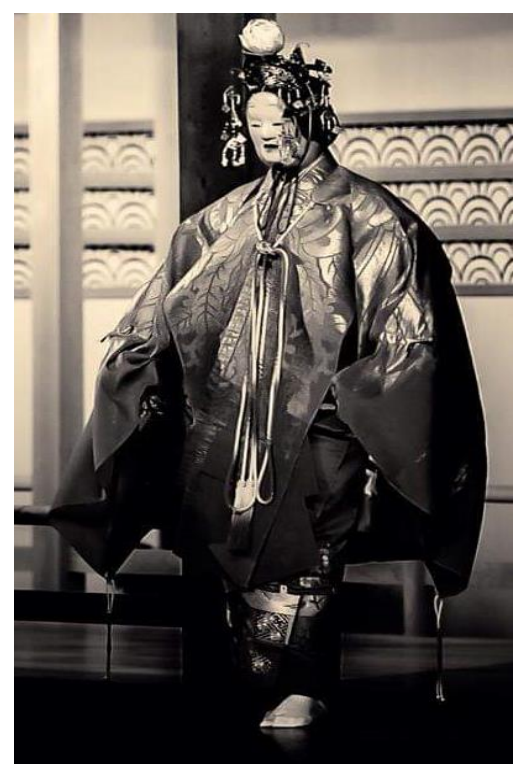

Figure 1: Hagoromo played by Tatsushige Udaka in Kyoto (Documentation by Tatsushige Udaka, 20 September 2014). 


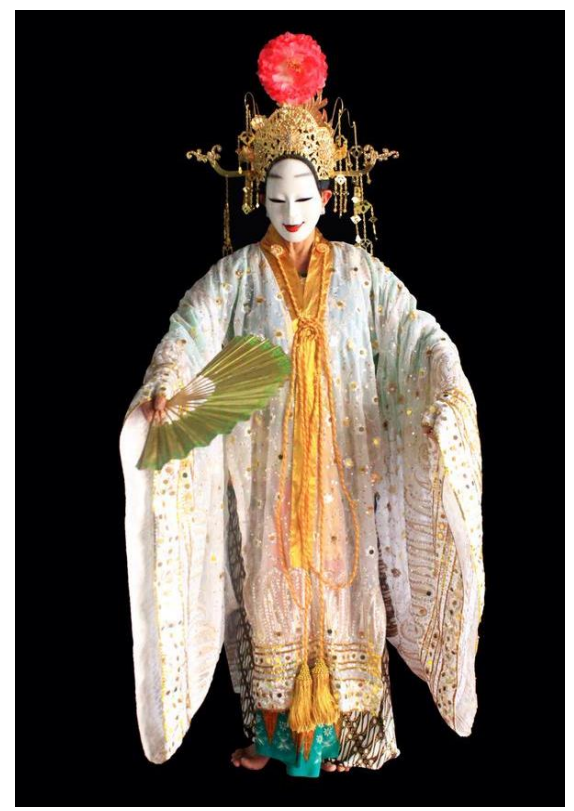

Figure 2: Endhel role taken from the Goddess character in the play of Hagoromo. Didik Nini Thowok has used the mask, head accessories, and cloak in his creativity and interpretation of the collaborative play (Documentation by LKP Natya Laksita, September 2014).

The literature transformation can be observed in the character of the goddess played by Didik Nini Thowok as Endhel dancer, identified through the costume's fashion and typical movement scene of Hagoromo play on a rakit gelar. Didik Nini Thowok keeps the original Javanese costumes of bedhaya dancers which are given additional embellishments to complete the costumes' appearance, such as peony crown, white robe, and Ko-Omote mask. Although it is not too similar to the original, the creativity of Didik Nini Thowok through Hagoromo play has indeed fused into the artwork, and portrays his soul as the Javanese bedhaya dancer. The costume's appearance is not the same as what is worn by the actor in the existing Hagaromo of Noh drama tradition, but Didik Nini Thowok has given his best efforts to visualize Nawang Wulan as well as the Goddess from Hagoromo story by musicalizing the distinctive poem of Hagoromo play "azumaaobi no, kazuni, sononamotsuki no" in the ending part of rakit gelar.

Bedhaya Hagoromo is clearly different from the Bedhaya dance directed by the royal palace or other artists who are involved in the development of dance in the palace other than the Yogyakarta Sultanate, as well as in the Duchy of Puro Pakualaman. The framework of bedhayaputri dance in a style of Yogyakarta Sultanate underlies Didik's dance creation by including the distinctive elements of Noh drama and his interpretation to Jaka Tarub Nawang Wulang and Hagoromo story. Didik Nini Thowok has filed for copyright and novelty by compiling the combination of both cultural entities (Javanese and Japanese) in the context of proper performance. The presence of Sri Sultan Hamengku Buwono X has been a strong momentum in pursuing the same styles and levels of collaboration, quality, and value.

Didik Nini Thowok did not change the standard traditional pattern of Bedhaya dance that is wellknown in the community. However, rakit gelar became the medium for him to convey the story of Jaka Tarub Nawang Wulan, followed by Hagoromo play, incorporating the movements of Javanese dance and Japanese's Noh that had been modified. The manifestation of waki by Akira Matsui, chanting of kandha in a distinctive Japanese intonation, were later added with the combination of movements in ngenceng encot kipas (ngenceng) is the main dance movement for female character in Yogyakarta classical court dance which incorporated the use of fan (adapted from Noh drama movements in this play), fashion styling of Endhel role who plays Hagoromo, and the ending part, performed with the dance as a symbolization to Sri Sultan Hamengku Buwono $\mathrm{X}$ as well as the invented novelty elements, made this overall dance work of Didik Nini Thowok to be more creative than his previous works, and also bedhaya dances created by other artists, either in Yogyakarta or in other parts of the world. 


\section{The Study of Literature Transformation in Bedhaya Hagoromo Dance}

The name of Bedhaya Hagoromo dance consists of two words, 'bedhaya' and 'hagoromo' which indicates that the dance incorporates Hagoromo as the content of the story for the dance that will be presented on rakit gelar for the Bedhaya dance performance. Apart from that, the Bedhaya Hagoromo dance also includes the story of Jaka Tarub Nawang Wulan as part of the contents, although Jaka Tarub Nawang Wulan is not included in the title of this work by Didik Nini Thowok. However, the dance title is not a problem as many bedhaya dance repertoires use the name of 'Gendhing' on some parts, such as Bedhaya Sinom or Bedhaya Pangkur.

The conflict or possible clashes between two art entities, which are Bedhaya with Noh are not shown, but portrayed through adjustments made in the basic frame of Bedhaya dance that still accomplishes the standard of the dance, floor pattern (rakit), costume styling accompaniment, and the staging room.

The literature transformation applied in Bedhaya Hagoromo dance is not only adapting from one folklore, but the collaboration of two folklores which come from two different cultural backgrounds. Didik Nini Thowok plays the important roles as the dance creator, composer, and organizer of the dance performance, so that his dance creation and background as an artist who develops the Javanese culture, can be a good source of reference to members of the authority and society.

The perception of collaborators can be based on two things; namely which are seen from their art, and what becomes to another's art. Self-owned art will be oriented towards the thoroughness of the artwork so that good and bad criteria of the work creation are known, with regards to certain techniques and aesthetic standards. Meanwhile, the art belonging to others will be oriented only towards interesting and prominent factors without having to be burdened with an understanding of the whole manifestations although there are many breathtaking factors (Dea, 2005). In this case, Bedhaya Hagoromo was completed in its composition by Didik Nini Thowok with the good proportion of aspects in aesthetical and artistic standards. Then, he put the prominent aspects from Hagoromo plays into the Noh drama tradition. Therefore, he was trying to unite the diversity in performing arts strategy. On the other side, Didik Nini Thowok has also made a collaboration with cross-gender artistes and musicians, as well as all involved from the production team.

Didik Nini Thowok is an expert who has in-depth understanding of how to organize collaborative work according to the cultural space he lives in, although other collaborated elements are not to be ignored too. These versatility and adjustments occur in collaborative works as well as in literature transformation, i.e. from folklores into dance works.

The literature transformation of Jaka Tarub Nawang Wulan story begins with kandha which later collaborates with Hagoromo on rakit gelar. Rakit gelar is one of the important parts in the classical bedhaya court dance from Java. Also, Bedhaya Hagoromo has shown about how the two stories could be understood as a collaboration to be perceived by the audience, because of the role of the nymphs (Nawang Wulan and the nymph in Hagoromo) are interlocked in the performance. Apart from the drama, the dance is also presented live to the audience, so that the old fairy tale behind the story or folklore can be conveyed in the language that is understood by the audience (Damono, 2018). Rakit gelar refers to the presentation of the sequence and dance movements that describes the nymphs flying down to the earth and having shower in the lake. This part is adapted from Jaka Tarub Nawang Wulan stories where the dancer used dance movements called muryanibusana (namely, the make-up done by themselves). The next sequence is Hagoromo part, when Endhel dancer plays the role as the nymph in Hagoromo play. Didik Nini Thowok has used the language that could be understood, as explained by Damono through the role in the dance and all of the bedhaya performance.

Didik Nini Thowok has conveyed the idea of creation as well as the stories incorporated into his work by using traditional dance as the 'language,' namely a type of bedhaya that is known to the Javanese people, especially in Yogyakarta. Therefore, no doubt arises in presenting the folklore of Jaka Tarub Nawang Wulan which is combined with Hagoromo play in Bedhaya dance for Javanese people who comprises of the majority of the audience. Besides actualizing the literature transformation from folklore into another medium of dance, this strategy is also used to bring back the practice of Bedhaya Kakung dance that once existed in the Palace environment on Sri Sultan Hamengku Buwono V era (1823-1855).

Transformation, according to Damono (2018), means "changing, and changing means creating something different from the previous work" (p. 152). Bedhaya Hagoromo involves the the transformation from a particular text to the newest text form. The work of textual collaboration has made the intertextual work seem merged or not merged without dissolving the essence of a particular entity. It seems that the strategy to involve Hagoromo play (Noh drama) from Japan in the form of bedhaya dance, as well as 
incorporating Javanese language tradition, is a good effort in performing a new dance which will implement cross-cultural collaboration, important in the globalization era that facilitates the accessibility of information exchange and cultural contents between nations.

\section{Conclusion}

The literature transformation applied in the dance performance of Bedhaya Hagoromo from the beginning of its appearance until its last performance in 2004, did not only actualize new forms, but also showed unusual effort done, especially in the process of creating it. The way the dance/creator and audience interpret this dance, must be taken into consideration.

Jaka Tarub Nawang Wulan and Hagoromo story portray the same characteristic, which is the virtues of the human world and the supernatural world. Both stories come from two countries with different cultural backgrounds, but the similarity in the essence of the story can be discovered. The characters of human and Goddess can be referred as dichotomy analogy between 'the good' and 'the bad.' This can be observed from the character of Goddess coming from the heaven (sky) in which both stories portray 'obedience.' This message of morality is clearly explained by Zeami Motokiyo in the script of Hagoromo which is translated into English by Arthur Walley, from the conversation between the Goddess with Hakuryo that mentioned "world is a space of lies, and there is no such kind of thing in heaven."

Literature transformation not only changes an original form to the new one, but also conveys moral values that exist in the story. In other words, the transmission value is incorporated well in its distinctive form. The performance of Bedhaya Hagoromo dance is also a form of 'obedience' of Didik Nini Thowok to Sri Sultan Hamengku Buwono X, the exalted King; where the transmission of moral value in the story could not ignored in this case. The essential points that can be concluded from this study are (1) literature transformation from the folklores of Jaka Tarub Nawang Wulan-Hagoromo which is presented in its new medium with a novelty, is based on the artistic and aesthetic interpretation of Didik Nini Thowok that is embodied in the form of presentation aspects, namely dance movements, dance accompaniment, floor pattern (rakit), altogether with the dance parts, rakit gelar presentation, costume styling, and other elements related to Hagoromo play in the Noh drama tradition; (2) the work done in this literature transformation is very complicated because it adapts from the collaboration of two folklores, Jaka Tarub Nawang Wulanand Hagoromo without clashing with each other, so that the adjustments made can result in the dance's distinctive presentation without any domination from both stories; and (3) this literature transformation not only combines two folklores into a new bedhaya dance composition, but implicitly contains the strategy using the new frame work of bedhaya dance or traditional language from bedhaya dance (kakung) to enable it to exist again now a days, as an effort of manifestation on the presence of Didik Nini Thowok as one of the cross-gender artists in Indonesia who has published in the event book entitled 'REBORN: Homage to Sri Sultan Hamengku Buwono X and Yogyakarta by Didik Nini Thowok in 2014.

\section{References}

Bowers, F. (1984). Japanese theatre: Origin, noh drama, puppets, kabuki spectacle, 3 kabuki plays in translation. actor and playwrights, present day trends. Charles E. Tuttle Company.

Damono, S. D. (2018). Alih wahana. PT. Gramedia Pustaka Utama.

Dea, A. (2005). Reaching beyond collaboration: A close look and evaluation of three inter-cultural experiences in Central Java. In Nor, M. A. M. \& Murugappan, R. (Eds.) Global \& local dance in performance (pp. 317333). Cultural Centre, University of Malaya \& Ministry of Culture, Arts and Heritage Malaysia.

Hadi, Y. (2011). Koreografi: Bentuk, teknik, isi. BP ISI Yogyakarta.

Kusmayati, A. H. (2015). Ragam seni pertunjukan tradisi \#4: Dokumentasi tari klasik. Dinas Kebudayaan Daerah Istimewa Yogyakarta.

Suharti, T. (2015). Bedhaya semang karaton Ngayogyakarta Hadiningrat reaktualisasi sebuah tari pusaka. PT. Kanisius.

Surjodiningrat, R. (1971). Gamelan dance and wayang in Jogjakarta. Gadjah Mada University Press.

Wibowo, D. E. (2015). Makna simbolis tari bedhaya hagoromo karya didik nini thowok (Accession No. 1011288011) [Unpublished bachelor's thesis, Institut Seni Indonesia Yogyakarta]. Institutional Repository Institut Seni Indonesia Yogyakarta.

Wibowo, D. E. (2018). Kreativitas didik nini thowok dalam tari bedhaya hagoromo tahun 2014 [Unpublished master's thesis, Gadjah Mada University]. Institutional Repository Gadjah Mada University Yogyakarta. 


\section{Acknowledgements}

I would like to convey my deepest gratitudes to Didik Nini Thowok for giving the opportunity to learn and observe how literature transformation works in the dance collaboration of Bedhaya Hagoromo; Tatsushige Udaka as the Noh Kyoto's actor for the information and sharing of the documentation while performing as Hagoromo, and also Siti Sutiyah (NyiKRT. Dwija Sasmintamurti) and Theresia Suharti (NyiKRT. Pujaningsih) for the advice and information while learning and discovering more on Yogyakarta dance style performed by female characters or Puteri. 